\title{
correspondence
}

\section{Select Committee's future}

SIR,-In its recent First Report (17 July, 1978) the Select Committee on Procedure proposed some important and far-reaching changes in the procedure of the UK House of Commons. These include the establishment of a separate select committee for each of the departments of government, or groups of departments.

Our concern in this letter is with only one of the proposals, namely the dissolution of the Select Committee on Science and Technology whose work, it is said (paragraph 5.40), "should in future be carried out by the departmentallyrelated committees ..." This proposal is supported in the report by an argument to the effect that the proposed new committees "would in no way be inhibited from taking evidence from any government department or other body relevant to the studies which they undertake."

Nevertheless, it is the view of the Executive Committee of this council that such a decision would be a retrograde development. We strongly support the opinion expressed to the Select Committee on Procedure by Mr Arthur Palmer MP, the Chairman of the Select Committee on Science and Technology, as indicated in paragraph 5.40 of the First Report. Departmental committees, said $\mathrm{Mr}$ Palmer, could not "adequately meet the need for parliamentary scrutiny of scientific and technological developments" since "inter-departmental subjects, however important they might be, would be accorded a lower priority".

The Committee on Procedure's argument depends on the generality of the policy of spreading science research and development amongst the departments of government. From many points of view there are good reasons for continuing this policy, where "after brief experiments in the 1960 s with co-ordinating ministries, governments of all complexions have decided to leave scientific and technical research in the hands of individual ministries with only vestigial co-ordinating functions remaining at the centre" (paragraph 5.19). It does not follow from this, however, that the scrutiny of these activities should be compartmentalised to the same degree. Indeed, it is precisely because the central coordinating functions for scientific and technical research are vestigial that the work of the Select Committee on Science and Technology is so valuable.

Presumably, within the proposed system, there would be parliamentary committees for each of the Departments of Education and Science, Energy, Environment, and Industry, and perhaps other departments as well, all dealing with particular aspects of science and technology. Such committees would, undoubtedly, serve a valuable purpose in scrutinising the day-to-day, ongoing, short-term, research that is central to the work of each department. But no amount of "liaison and cooperation" between such committees "to allow joint inquiries and consultation, where committees share an interest" (paragraph 5.20), could deal satisfactorily with the broader, long-term, issues of science and technology.

This can be seen at once from the issues that have already been taken up by the Select Committee on Science and Technology. These were necessarily concerned with scientific and technological questions drawn from a whole range of departments such as energy, environment, industry, health and social security, etc. Current issues of great political, social and economic significance, such as the potential benefits and hazards of genetic manipulation or the future effects of electronic microprocessors, obviously overflow all the boundaries appropriate for the administration of science and research within the government machine. By its terms of reference, which encourage it to scrutinise positively the activities of the executive on such issues right across the board, the Select Committee on Science and Technology fulfills an indispensable role on behalf of the lay public which its members are elected to represent. From the experience of our council and the detailed studies that we have made of policies and procedures relating to the social and political context of science and technology, it is clear that this is a role that should be considerably strengthened, rather than weakened, as proposed. As an institution endowed with all the constitutional authority of Parliament, capable of mediating effectively between the various domains of scientific expertise, governmental administration, and the concerns of the general public, the Select Committee on Science and Technology is potentially one of the most valuable social instruments available to us in times of rapid and bewildering technical change.

In the past the Select Committee on Science and Technology has not always been able to achieve this full potential. From our own close contact with members of that committee, and from our observation of its work, this is not due to any fundamental defect in its terms of reference, but rather to the very limited permanent staff resources, and restrictions on the appointment of specialist advisors, under which the committee has laboured. These deficiencies are recognised in the First Report from the Select Committee on Procedure, which recommends much improved arrangements in this respect. In our view, it is ironical that these resources should now be made available to new select committees which are to be much more closely linked to particular departments where technical staff resources abound, whilst proposing to terminate a committee which has been weakened by lack of such resources.

In our view, the proposed new system would perpetuate, in a most unsatisfactory manner, the split between science and technology which occurred when the DES was first created. Furthermore, there are many areas within technology itself which cannot be neatly divided into the interests of Departments of Energy, of the Environment, of Industry, etc. This fragmentation is not merely inconsistent with the realities of modern scientific research and technological innovation. It also takes a narrowly instrumental view of the contributions of various expert disciplines to the issues raised by technical change. It is not so much, as the report suggests (paragraph 5.42), "that scientific and technical matters in widely varying fields involve a common approach which can best be handled by common methods"; it is rather that many current issues and policies cannot be adequately scrutinised except from a point of view that transcends and integrates the separate departments of government. The various proposed departmental committees, however loose their terms of reference and however well "coordinated" they might be over particular issues, could not adopt a sufficiently comprehensive viewpoint where social, environmental, economic, health and safety and industrial factors would be related to narrower technical or administrative matters.

We hope, therefore that Parliament will consider very carefully before dissolving the Select Committee on Science and Technology. Whether or not departmental committees are created, we believe that the Select Committee on Science and Technology should be retained. Its broad remit it seems to us, is just what is needed for the purpose of taking an overview of the various areas where pure science interacts with all the separate branches of technology, and where these branches interact with each other and where they may also have far-reaching social consequences.

JoHN ZiMaN

Council for Science and Society, London, UK.

\section{Scientist-entrepreneurs}

SIR,-One aspect was not mentioned in the article by Dickson ( 5 April, page 494) concerning the commercial payoffs of recombinant DNA research. It is clear from the article that one of the 'fall-outs' of recombinant DNA research is the emergence of a group of scientistentrepreneurs. Practically all the research which has led to the discovery and techniques of recombinant DNA was funded by public monies. It is obvious from the article that the recipients of these grants have jumped in with both feet in aiding to set up commercial companies to capitalise on the possible future profits resulting from the large-scale exploitation of recombinant DNA techniques. One wonders who will gain the monetary profits-only the stockholders of the companies or the scientist-entrepreneurs as well. One also wonders at the disinterestedness of the scientists, who clamoured for no restrictions on the research, giving as a reason the possible great public health benelts which might result. It seems clear now that if the benefits materialise they will accrue not only to the public, but also to the companies and the scientists. It seems to me that there is an ethical issue in all this, for while in our capitalistic society companies are supposed to make money, in our scientific society scientists are supposed to search for 'the truth', for the benefit of all and are not supposed to make money from their research, particularly if it was funded by public monies. 